\title{
Evolutionary history of stomach bot flies in the light of mitogenomics
}

\author{
Liping Yan ${ }^{1}$, Thomas Pape ${ }^{2}$, Mark A. Elgar ${ }^{3}$, Yunyun Gao ${ }^{1}$, Dong Zhang ${ }^{1, *}$ \\ ${ }^{1}$ School of Nature Conservation, Beijing Forestry University, Beijing 100083, China \\ ${ }^{2}$ Natural History Museum of Denmark, University of Copenhagen, Copenhagen 2100, Denmark \\ ${ }^{3}$ School of BioSciences, University of Melbourne, Melbourne, Victoria 3010, Australia \\ *Correspondence: ernest8445@163.com, zhangdong_bjfu@bjfu.edu.cn
}

\begin{abstract}
Stomach bot flies (Oestridae: Gasterophilinae) are obligate endoparasitoids of Proboscidea (i.e., elephants), Rhinocerotidae (i.e., rhinos) and Equidae (i.e., horses and zebras, etc.), with their larvae developing in the digestive tract of hosts with very strong host specificity. They represent an extremely unusual diversity among dipteran, or even insect parasites in general, and therefore provide significant insights into the evolution of parasitism. The phylogeny of stomach bot flies (Calyptratae: Oestridae, Gasterophilinae) was reconstructed based on extensive mitochondrial molecular data for Cobboldia, Gyrostigma and six of the eight known species of Gasterophilus. The phylogenetic tree, i.e. (Cobboldia, (Gyrostigma, (Gasterophilus pecorum, (Ga. intestinalis, (Ga. haemorrhoidalis, Ga. inermis)), (Ga. nasalis, Ga. nigricornis)))), provides a strong evolutionary reference to infer several biological patterns for the first time for this group: 1) host shifts of stomach bot flies from elephants to rhinoceroses and then from rhinoceroses to equids; 2) dispersal with their hosts from the Afrotropical region into the Palaearctic and Oriental regions; 3) oviposition site, originally on the host head, and egg production positively correlated with distance from the mouth; 4) attachment of $3^{\text {rd }}$ instar larva originally in the stomach, with duodenal and large intestinal positions secondarily derived; and 5) guanine and cytosine (GC) enrichment of the mitogenome as an adaptation to larval life in the warm environment of the host digestive tract, combined with the need for a high evolutionary rate to cope with the fast evolution of their mammalian hosts.
\end{abstract}

This is the author manuscript accepted for publication and has undergone full peer review but has not been through the copyediting, typesetting, pagination and proofreading process, which may lead to differences between this version and the Version of Record. Please cite this article as doi: 10.1111 /syen.12356 


\section{Introduction}

Parasites sensu lato comprise nearly half of animalian diversity (De Meeûs \& Renaud, 2002), with parasitism estimated to have evolved independently at least 223 times (Weinstein \& Kuris, 2016). Parasite life-cycles typically comprise three stages: transmission, infection and establishment (Read, 1972; Zelmer, 1998), and each may require specific adaptations, depending upon the degree of host-specificity of the parasite. Transmission to hosts may depend on host-specific oviposition strategies (e.g., Stireman et al., 2006); infection may require mechanisms that ensure the parasite progeny to enter, attach to or associate with the host (e.g., Nufio \& Papaj, 2004); and establishment requires the parasite progeny to locate and remain in particular sites within, on or associated with the host. These three properties of parasitism, which may be highly host specific, make host shifts remarkable events of considerable evolutionary interest (De Fine Licht, 2018), especially when they result in speciation (e.g., nudibranchs (Faucci et al., 2007), and parasitic flatworms (Zietara \& Lumme, 2002)).

Parasitism has evolved numerous times within Diptera (Grimaldi \& Engel, 2005; Courtney et al., 2017), and more frequently than within any other group of insects (Feener \& Brown, 1997; Wiegmann et al., 2011), and even of animals (Weinstein \& Kuris, 2016). Bot flies (Oestridae) are obligate larval endoparasites of mammals (Colwell, Hall \& Scholl, 2006; Guimarães \& Papavero, 1999; Zumpt, 1965), which is an unusual lifestyle among Diptera, with a possible early or mid-Eocene origin (Pape, 2006; Cerretti et al., 2017; Stireman et al., 2018). Bot flies may be the first dipteran group to have evolved mammal myiasis, and with approximately 160 extant species (Pape et al., 2011, 2017), are by far the largest radiation of dipteran mammal endoparasites. While conventionally defined as endoparasites, the transmission biology of bot flies, with free-living adults, more closely resembles that of insect parasitoids, and so they may be more usefully referred to as mammal endoparasitoids (Zelmer, 1998) even if they do not kill their host. The larvae of most bot flies are subcutaneous parasitoids, but stomach bot flies develop in the digestive tract of their hosts with very strong host specificity (Colwell, 2006; Zumpt, 1965). The biology of this small group of bot flies is not only extremely unusual within Diptera, but across the entire 
Insecta (Balashov, 2006).

The stomach bot flies contain three genera, Cobboldia Brauer, Gyrostigma Brauer, and Gasterophilus Leach, which are respectively parasitoids of Proboscidea (i.e., elephants), Rhinocerotidae (i.e., rhinos) and Equidae (i.e., horses, zebras, etc.) (Zumpt, 1965). Females oviposit on different areas of the host body (with one exception where eggs are laid on the food plants), and the $1^{\text {st }}$ instar larvae (LI) may hatch spontaneously or following host stimulation, subsequently entering the digestive tract through the mouth. Larval development lasts up to ten months, with the mature $3^{\text {rd }}$ instar larvae (LIII) leaving the host with the faeces via the anus. After leaving the host, the larvae pupate in the ground, eventually eclosing as adults to mate and oviposit. All stomach bot fly larvae attach to the wall of the digestive tract of their hosts, but the specific location varies among species. For example, there is evidence that the larvae of Cobboldia attach to the elephant stomach wall (Gowda et al., 2017); the $2^{\text {nd }}$ instar larvae (LII) and LIII of Gyrostigma attach to the stomach wall of their rhinoceros host (Zumpt, 1965); while the LIII of all Gasterophilus species attach to different locations along the digestive tract of their equine host (Horak, Vos \& Klerk, 1984; Zumpt, 1965). Detailed life-history information for each stomach bot fly species is summarized in Table 1. With 14 known extant species (three species of Cobboldia, three of Gyrostigma, and eight of Gasterophilus), the stomach bot flies have a modest species richness (Pape, 2006), but this should be considered in the context of the constraints of their specialized niche, and many species are likely to have become extinct with their host, like Cobboldia russanovi Grunin found from the woolly mammoth (Grunin, 1973).

We used data from the mitochondrial genome, which plays an important role in systematic research (e.g., (Barker, 2014; Cameron, 2014; Timmermans et al., 2014; Zhang et al., 2016a; Horreo, 2017)), in order to reconstruct the phylogeny of the stomach bot flies. We used this phylogeny as an evolutionary framework to explain the life-history strategies as a result of diversification through shifts in hosts, oviposition sites, female fecundity and larval attachment sites, within this highly specialised group of remarkable parasitoids. 


\section{Materials and Methods}

DNA extraction, sequencing, and annotation

DNA was extracted from LIII or adults preserved in $99.5 \%$ ethanol (File S1) following the protocol described in (Zhang et al., 2016a) and stored at -20 deg. Celsius dissolved in Tris-EDTA buffer until use. Mitogenomic data for Cobboldia and Gasterophilus were amplified using primer pairs following polymerase chain reaction (PCR) protocols in File S2. PCR reaction, amplicon sequencing, and fragment assembly were performed as described in (Zhang et al., 2016a). Only the gene for Cytochrome c oxidase subunit 2 (COII) and a part of the gene for subunit 1 (COI) were successfully amplified and sequenced for Cobboldia loxodontis (Brauer) because of limited amounts of DNA extracted from a single leg of the most recently collected, available specimen (S1). The mitogenome of Gyrostigma rhinocerontis (Owen) was obtained by genome skimming from next generation sequencing (NGS) data following (Crampton-Platt et al., 2015).

BLAST search (Altschul et al., 1990), MITOS search (Bernt et al., 2013) and DNAMAN software (version 8, Lynnon Corp., Canada) with another Oestroidea mitogenome as reference were used to identify genomic positions and gene boundaries of protein-coding genes (PCGs), ribosomal RNA (rRNA) and transfer RNA genes (tRNA). Nucleotide composition and codon usage were calculated using MEGA7 (Kumar et al., 2016).

Base composition and substitution rates

Mitogenomes of 46 calyptrate species (File S3) were used for base composition estimation. Base compositions of each of PCGs (for all three codon positions together and for each codon positions separately), rRNA and tRNA genes, concatenated PCGs, rRNA and tRNA genes respectively, and complete or nearly complete mitogenomes were calculated using MEGA7 (Kumar et al., 2016).

For calyptrate families with more than one mitogenome available, we selected one species from each genus (File S3) and calculated family-specific Tamura-Nei (TN) substitution rates using MEGA7. Pairwise 
distances of all 13 PCGs for substitutions at fourfold degenerate sites, and numbers of synonymous and non-synonymous substitution per site were calculated following Eo \& DeWoody (2010), i.e., dividing total number of substitutions by divergence time, with divergence time of each family obtained from Cerretti et al. (2017).

\section{Phylogenetic analysis}

A total of nine oestrid mitogenomes, including the previously documented mitogenome of Ga. pecorum (Fabricius) (Zhang et al., 2016a) plus mitogenomes from one exemplar species from each of the bot fly subfamilies Hypodermatinae (Hypoderma lineatum (Villers)) and Cuterebrinae (Dermatobia hominis (Linnaeus)), were included in the present study (Table 2).

Phylogenetic analyses were conducted using the 13 PCGs and two rRNA genes. Each mitochondrial gene was aligned separately using MAFFT v7.310 (Katoh \& Standley, 2013). For PCGs, the option L-INSi was used, with iterative refinement method incorporating local pairwise alignment information (-localpair). After aligning, all alignments were translated into amino acid sequences in MEGA7 and adjusted to ensure reading frame fidelity. The same aligning parameters were used for rRNA genes, except that QINS-i was used, since the secondary structure of RNA is considered by this strategy. Individual alignments were then concatenated into a final matrix using SequenceMatrix v1.8 (Vaidya et al., 2011).

Phylogenetic trees were generated using Bayesian Inference (BI) and maximum likelihood (ML), with dataset partitioned by gene. The best partitioning scheme and substitution model for Bayesian Inference was evaluated using PartitionFinder2 (Lanfear et al., 2017), after the "greedy" algorithm with branch lengths estimated as "linked", following the AICc. Bayesian Inference was then conducted at the CIPRES webserver (Miller et al., 2010) (https://www.phylo.org/) using MrBayes 3.2.6 (Ronquist \& Huelsenbeck, 2003). Two independent runs were conducted, each with four chains (one cold and three hot chains), for 10 million generations, and samples were drawn every 1000 generations. The first $25 \%$ of steps were discarded as burn-in.

The ML analyses were performed using IQtree (Nguyen et al., 2015), based on the best partitioning 
strategy searched by the self-implemented ModelFinder (Kalyaanamoorthy et al., 2017). Node support values were estimated with standard bootstrap resampling. The resulting trees were visualized using the iTOL online tool (https://itol.embl.de) (Letunic \& Bork, 2016).

\section{Reconstruction of ancestral states and ancestral distribution}

Since phylogenetically closely outgroups and relatively dense sampling are crucial to determine the ancestral node states, especially for MP reconstruction (Salisbury \& Kim, 2001), Ga. ternicinctus Gedoelst and Ga. meridionalis (Piller \& Evans) were added to the phylogeny based on the sparse existing morphological evidence in order to perform reconstructions on a complete taxon coverage (see Results).

Data on distribution and biology (Table 3; summarized in File S4) were collected from Zumpt (1965) and other relevant literature (e.g., Horak et al., 1984b). Parasites of domestic hosts will often have greatly expanded their geographic distribution along with that of their hosts, and we have attempted to code what we consider as original (i.e., pre-human) distributions. The distribution is accordingly coded as Palaearctic for Ga. intestinalis (De Geer) as well as for the outgroup H. lineatum.

S-DIVA (Yu et al., 2010) (modified from DIVA; Ronquist, 1997), is often used for biogeographical reconstructions, based on the assumption that speciation is caused by vicariance and minimising implied dispersal and extinction events (Ronquist, 1997). Such vicariance (or separation/isolation) during speciation could happen not only spatially, but also temporally (e.g., Filchak et al., 2000), or along with habitat divergence (e.g., Linn et al., 2003). Two developmental strategies of Gasterophilus spp. (choice of oviposition site and LIII attachment site) involve the physical position of specific immature stages, and like geographical data they can be considered as evolving through processes equivalent to dispersal and vicariance. S-DIVA was used for reconstructing ancestral distributions and the ancestral states for oviposition site and $3^{\text {rd }}$ instar larval attachment site.

No phylogenetic hypothesis has been proposed previously for the four known species of Cobboldia $(C$. elephantis (Cobbold) (Oriental), C. loxodontis Brauer (Afrotropical), C. roverei Gedoelst (Afrotropical), C. 
russanovi (Palaearctic; extinct)). This prevents a specific reconstruction of the ancestral area, i.e., of the distribution of the hypothetical ancestor of Cobboldia, and alternative analyses were therefore performed with the distribution of Cobboldia coded as either Afrotropical + Palearctic + Oriental or Afrotropical.

Oviposition sites were divided into three different states: non-host environment, non-head area of host, and head area of host (Table 3). The distinction between head and non-head area of a host assumes that eggs deposited on the head are closer to the mouth and thus the newly hatched larva have a higher probability of reaching the host mouth and alimentary canal. Ancestral states of oviposition sites were reconstructed using maximum parsimony (MP) implemented in Mesquite (http://mesquiteproject.wikispaces.com/home) Version 3.2, and Bayesian Binary MCMC (BBM) modified from MrBayes 3.1.2 (Ronquist \& Huelsenbeck, 2003) performed in RASP (Yu et al., 2015). The BBM methods followed the JC model. Reconstructions using S-DIVA were not possible for the complete phylogeny, as this method requires a complete character coding (i.e., no missing states), thus our analysis was performed without the two species whose oviposition sites are unknown.

The LIII attachment sites were divided into five states (subdermal tissue, pharynx, stomach, pylorus and duodenum, and large intestine), and reconstructed using MP and BBM as described above, with additional reconstruction in S-DIVA performed in RASP.

\section{Results}

\section{General features of Gasterophilinae mitogenomes}

The total length of the mitogenomes of five Gasterophilus species ranges from 14,590 bp to $14,854 \mathrm{bp}$ (File S5). After assembling and annotating, they were registered in the GenBank database (assigned accession numbers are given in Table 2). Each mitogenome contains the usual 13 PCGs, 22 tRNA genes, two rRNA genes and a non-coding region (the trnI gene was not sequenced for Ga. nigricornis (Loew) due to technical difficulties). Similar to other oestroid flies (e.g., Zhang et al., 2016a; Yan et al., 2017), most mitochondrial genes in the present study are encoded on the majority strand (J-strand) with 23 genes (nine 
PCGs and 14 tRNA genes), and 15 genes (five PCGs, eight tRNA genes and two rRNA genes) on the minority strand (N-strand) (File S5). The mitogenome of G. rhinocerontis obtained by genome skimming and mitochondrial genes of Cobboldia loxodontis are registered in GenBank (see Table 2 for accession numbers). All PCGs of Gasterophilus have one of the common start codons: ATG, TCG, ATA, or ATT, except for ATP8, which begins with ATC in Ga. haemorrhoidalis (Linnaeus) and Ga. inermis (Brauer), and with ATT in other Gasterophilus species. The majority of the PCGs terminate with TAA, TAG or T as stop codon, and only two PCGs (ND3 and ND4) have a slightly different termination (File S5).

\section{Base composition and substitution rates}

At the mitogenomic level, Gasterophilinae exhibit higher guanine and cytosine (GC) content than other oestrids and apparently all other calyptrates, and GC enrichment mainly occurs at $3^{\text {rd }}$-codon positions of PCGs and rRNA genes (Fig. 1A). Mitogenomic GC content of calyptrates included in the present study ranges from $20.03 \%$ (Elodia flavipalpis) to $31.76 \%$ (Ga. haemorrhoidalis). The GC content of PCGs varies from $20.86 \%$ (Elodia flavipalpis) to $33.44 \%$ (Ga. haemorrhoidalis), and of the $1^{\text {st }}-2^{\text {nd }}-$ and $3^{\text {rd }}$-codon positions ranging from $27.43 \%$ (Elodia flavipalpis) to $37.24 \%$ (Ga. haemorrhoidalis), $32.22 \%$ (Elodia flavipalpis) to $35.03 \%$ (Ga. nasalis), and $2.92 \%$ (Elodia flavipalpis) to $28.19 \%$ (Ga. haemorrhoidalis) respectively. Elodia flavipalpis has the lowest GC content of rRNA genes (16.51\%) and tRNA genes (20.23\%) while Ga. haemorrhoidalis and Ga. inermis have the highest GC content of rRNA genes (27.07\%), and Ga. nasalis (Linnaeus) the highest GC content of tRNA genes (26.01\%).

Oestridae $\left(0.09 \times 10^{-10}\right)$ show a much higher TN substitution rate than other calyptrate families (Figs. 1B1,1B2,1B3,1B4). Substitution rates at fourfold degenerate sites and synonymous sites show the same pattern as the TN rate, with the highest rate occurring in Oestridae, while for substitution rates at nonsynonymous sites, Tachinidae show the highest evolutionary rate, followed by Oestridae, Sarcophagidae, Muscidae and Calliphoridae. 


\section{Phylogeny of Gasterophilinae}

The ML and BI (average standard deviation of split frequencies: 0.000768; estimated sample size of all parameters above 1000; potential scale reduction factor of all parameters $=1.00)$ analyses provide identical results, with Gasterophilinae being monophyletic, and a well-supported, monophyletic Gasterophilus being sister to the species of the rhino stomach bot fly, G. rhinocerontis. Within Gasterophilus, Ga. pecorum is estimated to be the sister group of horse stomach bot flies, although with only modest support (Fig. 2). The remaining Gasterophilus are split into two clades (Ga. intestinalis (Ga. haemorrhoidalis + Ga. inermis)) and (Ga.nasalis $+G a$. nigricornis). The two Afrotropical endemics were placed on the cladogram based on their respective morphology. Gasterophilus ternicinctus was placed as sister to Ga. intestinalis based on their shared unique process on the hind trochanter (spatula-shaped in male and tubercular in female; Zumpt, 1965). Gasterophilus meridionalis was placed as sister to Ga. nigricornis based on shared features such as the first thoracic segment of LIII extended in a shelf-like manner over the pseudocephalon in $G a$. meridionalis, Ga. nasalis and Ga. nigricornis; and Ga. meridionalis and Ga. nigricornis with a rugose base of the mouthhook (Colwell, Otranto \& Horak, 2007; Li et al., 2018; Zumpt, 1965)).

\section{Ancestral area reconstruction}

Under the present taxon sampling, the hypothetical ancestral distribution of the stomach bot flies cannot be more precise than the distribution observed for Cobboldia (e.g. Afrotropical + Oriental + Palearctic) (Fig. 3; File S6). However, the Afrotropical region is reconstructed as the ancestral distribution for both the clade (Gyrostigma + Gasterophilus), and for all lineages of the Gasterophilus clade except for those leading to the clades ( $G a$. intestinalis $+G a$. ternicinctus) and (Ga. nigricornis $+G a$. meridionalis), of which the ancestral distribution in both cases are estimated as either Afrotropical or Palaearctic.

Estimates of the ancestral oviposition sites are similar between MP and BBM analyses (Fig. 4; File S6). The ancestral stomach bot fly most likely oviposited on the head of its host (62.54\% probability in BBM estimation, and the only possibility in MP estimation). The ancestor of (Gyrostigma + Gasterophilus) 
probably oviposited on the head of the host according to the MP estimation, while the BBM estimation favoured either the combined head + non-head area $(45.66 \%)$ or only the head area $(42.14 \%)$, with a $12.20 \%$ probability for an ancestral oviposition on a non-host (i.e., environmental) substrate. The ancestral horse stomach bot fly is also estimated to most likely have oviposited on the head area of the host, which is also the estimate obtained for most of the subordinate Gasterophilus nodes. In contrast, the S-DIVA estimation indicated the ancestral oviposition site of the ancestor of the clade ( $G a$. intestinalis ( $G a$. haemorrhoidalis + Ga. inermis)) to be the head + non-head area of the host.

The ancestral LIII attachment site for all stomach bot flies, for (Gyrostigma + Gasterophilus), and for Gasterophilus is estimated to most likely be the stomach, either as the only estimate or, for Gasterophilus, with a probability of $67.90 \%$ that is much higher than the next highest probability of $27.81 \%$ for a position in the combined area of pharynx and stomach (Fig. 5; File S6). The LIII attachment site of the ancestor of all Gasterophilus except for Ga. pecorum is estimated to most likely be the stomach in MP and BBM reconstructions, while it is either the stomach + pylorus-duodenum or the stomach + pylorus-duodenum + large intestine in S-DIVA reconstruction (node 18). Similar to the previous node, the estimation for the ancestor of ((Ga. intestinalis $+G a$. ternicinctus $),(G a$. haemorrhoidalis $+G a$. inermis $))$ in S-DIVA (node 15 , stomach + large intestine) is different from that in the MP and BBM estimations (most likely $=$ stomach). Estimations for the remaining nodes are identical.

\section{Discussion}

We reconstructed the stomach bot fly phylogeny using the most extensive molecular data and broadest taxon coverage currently available, including complete mitochondrial genomes from six of the known eight species of Gasterophilus, and for the first time with mitogenomic data for Gyrostigma and Cobboldia. The present phylogeny is similar to the morphology-based phylogenetic topology of Zhang et al. (2016b) in recovering Ga. Pecorum as the sister, and a well-supported sister pairing of Ga. nasalis and Ga. nigricornis. However, Zhang et al. (2016b) differs by having Ga. haemorrhoidalis group with (Ga. nasalis 
+ Ga. nigricornis) rather than with Ga. intestinalis in a clade with Ga. inermis and Ga. ternicinctus of the present study. The study by Zhang et al. (2016b) was based on a limited sample of 17 morphological characters with a narrow focus on the adult antenna, while the present study is based on complete mitogenomic data.

\section{Host shifts}

The evolution of host shifts is a significant issue in evolutionary biology (Vienne et al., 2013), and the conditions facilitating host shifts in parasites has attracted much attention (Fine Licht, 2018). Assuming proboscideans were the ancestral hosts of early stomach bot flies (Pape, 2006), then a host shift likely occurred from elephants to rhinoceroses no earlier than 20 MYA, and then from rhinoceroses to equines no earlier than 10.5 MYA. Our study supports that the ancestral distribution of stomach bot flies is the Afrotropical region (Pape, 2006). The arrival of the earliest Afrotropical rhinoceroses (Rhinocerotidae: Brachypotherium) (Geraads, 2010) from the northern continents 20 MYA provided opportunities for ancient elephant stomach bot flies to diversify by colonizing a rhinoceros host. Equids were absent from the Afrotropics until 10.5 MYA (Bernor et al., 2010; Franzen \& Brown, 2011), and host shifts of stomach bot flies from rhinos to equids must have occurred thereafter. These host shifts may have been facilitated by the habitat preferences and feeding habits of the hosts and thus the likelihood of oviposition mistakes. In the Afrotropics, Miocene elephants were mixed feeders with a dominant preference for browsing until $\sim 7.5$ MYA (Cerling et al., 1999), while rhinoceroses recorded from Africa (Geraads, 2010) were mainly grazers (Prothero et al., 1989), and equids had a dominant preference for grazing (Prothero et al., 1989; Bernor et al., 2010). This means that horses arriving in the Afrotropics would more likely be in the vicinity of rhinos rather than elephants, and thus the more likely target for oviposition mistakes. After colonizing new equid hosts, the diversification of the stomach bot flies led to the appearance of present-day species of Gasterophilus. 


\section{Origin and dispersal}

Our study suggests that stomach bot flies adapted to changes in the habitat imposed by the abiotic environment, rather than in response to migrating with their hosts. An Afrotropical origin of Gasterophilus is surprising because equids entered Africa as late as 10.5 MYA (Janis, 1993; Bernor et al., 2010; Franzen \& Brown, 2011), and ancient elephants or rhinoceroses infected with stomach bot flies would have had ample opportunities to associate with horses that were very common in Eurasia during the period 18-10.5 MYA (Franzen \& Brown, 2011). One explanation is that ancient stomach bot flies were strictly confined to tropical habitats, which would fit well with the notion that early bot fly evolution most likely took place in a humid tropical forest environment (Pape, 2006). Thus, the early stomach bot flies may not have entered Eurasia with their hosts because the environment was not suitable for the adult flies. Nevertheless, the ancient lineages of stomach bot flies must have adapted to the changing environment in the Afrotropical region, which became drier and cooler with the spread of savannahs since the mid-Miocene (Feakins \& Demenocal, 2010), and the ancestral Gasterophilus would have succeeded in colonizing early equids that had migrated into this region. The presence of Cobboldia russanovi in a woolly mammoth preserved in the permafrost of the Siberian tundra (Grunin, 1973) may be evidence that this adaptive shift also occurred in the genus Cobboldia, and is consistent with the view that stomach bot flies adapted in response to temporal changes in the abiotic environments rather than to spatial changes imposed with their early migrating hosts. The presence of Gyrostigma sumatrensis Brauer in the Sumatran rhinoceros (Dicerorhinus sumatrensis (Fischer)) may also fit this pattern. Although rhinoceroses used to be distributed in both Africa and Eurasia (Kalb et al., 1982; Benefit \& Monte, 1989), these Eurasian species may have been clear of stomach bot flies until a lineage evolved the capacity to survive, as adults, in a drier environment and subsequently spread into Eurasia (cf. fossil records: Kaya et al. (2012); Kazanci et al. (1999); Lehmann (1984)) and eventually colonizing the Sumatran rhinoceros before African and Eurasian rhinoceroses were completely isolated from each other (Prothero, 1993; Pandolfi \& Tagliacozzo, 2015). 


\section{Adaptations for oviposition}

Our phylogeny identifies the evolution of several adaptations associated with changes in host, and in oviposition and larval attachment sites. The head area was the primary oviposition site for all stomach bot fly lineages, and the morphology of the attachment organ (AO) on the eggs of stomach bot flies appears to be linked to their specific oviposition locations. The variation in fecundity (Table 1) of Gasterophilus is consistent with the balanced mortality life-history strategy associated with the mode of infection of LI (Stearns, 1992; Mayhew, 2016). The larvae of stomach bot fly species that oviposit on the head must reach the mouth of the host by active migration and these adults lay fewer eggs than species that oviposit away from the head, where larvae can only enter the host body by being ingested. Interestingly, the fecundity of Gy. rhinocerontis is similar to that recorded for $G a$. intestinalis - both produce about 700 eggs (Rodhain, 1915; Zumpt, 1965) - and both have similar oviposition sites on their rhinoceros and equine hosts respectively.

\section{Evolution in attachment site of $3^{\text {rd }}$ instar larvae}

According to our reconstruction, the stomach is likely to have been the preferred LIII attachment site of early stomach bot fly lineages. Our phylogeny reveals two shifts in the main location of LIII during the diversification of Gasterophilus: once from the stomach and into the large intestine, and once from the stomach and into the pylorus and duodenum. Attachment site selection by parasites is an active process, potentially leading to niche specialisation, and change in feeding strategy is thought to be one of the primary causes for differentiation in attachment site selection (Petter, 1962; Schad, 1963; Holmes, 1972). Similarly, the oral plates (Li et al., 2018) - i.e., the cephaloskeletal organ in Gasterophilus LIII that assists in feeding - varies (Principato, 1986), although species with the same attachment site have similar oral plate morphology. It is noteworthy that LIII of the species attaching to the pylorus and duodenum only have a single row of spines on each body segment (if there are spines at all), while other species of Gasterophilus have two to three rows of spines ( $\mathrm{Li}$ et al., 2018). The configuration and arrangement of 
body spines may be related to the attachment site, considering that peristalsis varies between stomach, duodenum and the large intestine (Van Weyenberg et al., 2006; Huizinga \& Lammers, 2008).

\section{Molecular adaptation of stomach bot flies}

Our study suggests that an intestinal parasitoid lifestyle has contributed to the evolution of genomic base composition in the stomach bot flies. The species of Gasterophilinae included in the present study have much higher guanine and cytosine (GC) content (in terms of overall mitogenome, PCGs and rRNA genes) than other calyptrates. Although the cause of GC content variation among and within genomes of organisms is still unclear, an environmental influence on the nucleotide composition of microbial genomes has been documented (Foerstner et al., 2005). The thermal adaptation hypothesis (Bernardi, 1995) argues that G:C pairs, which are connected by three hydrogen bonds, are more thermally stable than A:T pairs, which are connected by only two hydrogen bonds (Wada \& Suyama, 1986), and GC-rich genomes should accordingly ensure a more reliable protein synthesis due to more stable mRNA transcripts under higher temperatures (Bernardi, 1995). Consequently, high GC content could be expected to be found more often in animals with high body temperature (Bernardi, 2000; Mooers \& Holmes, 2000). Although the thermal adaptation hypothesis has been questioned [e.g., (Vinogradov \& Anatskaya, 2017)], our study lends some support to this hypothesis, especially as the accumulation of GC mainly happens at freely evolving sites (i.e., $3^{\text {rd }}$ codon position of PCGs) and rRNA genes (Hurst \& Merchant, 2001).

It is also believed that GC content covaries with mutation rate (Vinogradov \& Anatskaya, 2017; Kiktev et al., 2018), and that GC at $3^{\text {rd }}$ codon positions therefore accumulate in fast-evolving lineages (Romiguier et al., 2010). Therefore, the enrichment of GC in overall mitogenomes and at $3^{\text {rd }}$ codon positions of PCGs of stomach bot flies indicates their higher evolutionary rate compared with other calyptrates, which is possibly an effect of the evolutionary arms race between stomach bot flies and their hosts as implied by the Red Queen hypothesis (Van Valen, 1973) and as a means to survive in the challenging environment of the mammalian digestive tract. 


\section{Conclusions}

Stomach bot flies, the larvae of which are obligate gasterointestinal parasites of mammals, represent a very specialized group of animals, whose evolutionary history is only recently being illuminated through modern molecular/ phylogenomic methodologies. The unusual lifestyle of these flies, several species of which face a high risk of extinction (Colwell et al., 2009), can provide significant insights for understanding the evolution of parasitism in insects. We use mitogenomics to reveal an evolutionary history of the horse stomach bot flies, Gasterophilus spp. We estimate that all stomach bot fly lineages (elephant, rhino, and horse stomach bot flies) originated in the Afrotropics, with host shifts from elephants to rhinos and from rhinos to horses and a subsequent dispersal into the Palearctic and Oriental regions with their hosts. The head area is the ancestral oviposition site for all stomach bot fly lineages, and changes in fecundity evolved according to the probability of the $1^{\text {st }}$ instar larvae to enter the host mouth. The stomach is the ancestral attachment site for $3^{\text {rd }}$ instar larvae of all stomach bot fly lineages. A high GC-ratio may represent a molecular adaptation to life in the high-temperature or acid environment of the mammalian digestive tract.

\section{Acknowledgements}

We are grateful to Prof. Rudolf Meier (National University of Singapore, Singapore), Prof. Thierry Bourgoin (Muséum National d'Histoire Naturelle, France), and Prof. Adrian Lister (Natural History Museum, United Kingdom) and Dr. Juha Saarinen (University of Helsinki, Finland) for kindly providing valuable comments to the manuscript. This study was supported by the Fundamental Research Funds for the Central Universities (No. JC2015-04) and the National Science Foundation of China (No. 31572305 and 31872964). The authors declare no conflict of interest. 


\section{References}

Altschul, S.F., Gish, W., Miller, W., Myers, E.W. \& Lipman, D.J. (1990) Basic Local Alignment Search Tool. Journal of Molecular Biology, 215, 403-410.

Azeredo-Espin, A.M.L., Junqueira, A.C.M., Lessinger, A.C., Lyra, M.L., Torres, T.T., da Silva, F.R., Meirelles, F. V \& Maia, A.A.M. (2004) The complete mitochondrial genome of the human botfly Dermatobia hominis (Diptera: Oestridae). Unpublished Poster, ESA Annual Meeting and Exhibition. URL: Https://Esa. Confex. Com/Esa/2004/Techprogram/Paper_16801. Htm

Balashov, Y.S. (2006) Types of parasitism of acarines and insects on terrestrial vertebrates. Entomological Review, 86, 957-971.

Barker, F.K. (2014) Mitogenomic data resolve basal relationships among passeriform and passeridan birds. Molecular Phylogenetics and Evolution, 79, 313-324.

Benefit, B.R. \& Monte, L.M. (1989) New primate fossils from the Middle Miocene of Maboko Island, Kenya. Journal of Human Evolution, 18, 493-497.

Bernardi, G. (1995) The human genome: organization and evolutionary history. Annual review of genetics, 29 , $445-476$.

Bernardi, G. (2000) Isochores and the evolutionary genomics of vertebrates. Gene, 241, 3-17.

Bernor, R.L., Armour-Chelu, M.J., Gilbert, H., Karser, T.M. \& Schulz, E. (2010) Equidae. Cenozoic Mammals of Africa pp. 685-721. University of California Press.

Bernt, M., Donath, A., Jühling, F., Externbrink, F., Florentz, C., Fritzsch, G., Pütz, J., Middendorf, M. \& Stadler, P.F. (2013) MITOS: Improved de novo metazoan mitochondrial genome annotation. Molecular Phylogenetics and Evolution, 69, 313-319.

Cameron, S.L. (2014) Insect mitochondrial genomics: implications for evolution and phylogeny. Annual Review of Entomolgy, 59, 95-117.

Cerling, T.E., Harris, J.M. \& Leakey, M.G. (1999) Browsing and grazing in elephants: The isotope record of modern and fossil proboscideans. Oecologia, 120, 364-374.

Cerretti, P., Stireman, J.O., Pape, T., O’Hara, J.E., Marinho, M.A.T., Rognes, K. \& Grimaldi, D.A. (2017) First fossil of an oestroid fly (Diptera: Calyptratae: Oestroidea) and the dating of oestroid divergences. PLoS $O N E, 12, \mathrm{e} 0182101$.

Colwell, D. (2006) Life Cycle Strategies. The Oestrid Flies: Biology, Host-Parasite Relationships, Impact and Management, pp. 67-77. CABI.

Colwell, D., Hall, M. \& Scholl, P. (2006) The Oestrid Flies: Biology, Host-Parasite Relationships, Impact and Management, pp. 1-359. CABI.

Colwell, D.D., Otranto, D. \& Horak, I.G. (2007) Comparative scanning electron microscopy of Gasterophilus third instars. Medical and Veterinary Entomology, 21, 255-264.

Colwell, D.D., Otranto, D. \& Stevens, J.R. (2009) Oestrid flies: eradication and extinction versus biodiversity. Trends in Parasitology, 25, 500-504.

Courtney, G.W., Pape, T., Skevington, J.H. \& Sinclair, B.J. (2017) Biodiversity of Diptera. Insect Biodiversity pp. 229-278. Wiley-Blackwell.

Crampton-Platt, A., Timmermans, M.J.T.N., Gimmel, M.L., Kutty, S.N., Cockerill, T.D., Khen, C.V. \& Vogler, A.P. (2015) Soup to tree: The phylogeny of beetles inferred by mitochondrial metagenomics of a bornean rainforest sample. Molecular Biology and Evolution, 32, 2302-2316.

Eo, S.H. \& DeWoody, J.A. (2010) Evolutionary rates of mitochondrial genomes correspond to diversification rates and to contemporary species richness in birds and reptiles. Proceedings of the Royal Society B: Biological Sciences, 277, 3587-3592.

Faucci, A., Toonen, R.J. \& Hadfield, M.G. (2007) Host shift and speciation in a coral-feeding nudibranch. Proceedings of the Royal Society B: Biological Sciences, 274, 111-119.

Feakins, S.J. \& Demenocal, P.B. (2010) Global and African Regional Climate during the Cenozoic. Cenozoic Mammals of Africa pp. 45-55. University of California Press.

Feener Jr, D.H. \& Brown, B. V. (1997) Diptera as parasitoids. Annual Review of Entomology, 42, 73-97.

Filchak, K.E., Roethele, J.B. \& Feder, J.L. (2000) Natural selection and sympatric divergence in the apple maggot Rhagoletis pomonella. Nature, 407, 739-742. 
De Fine Licht, H.H. (2018) Does pathogen plasticity facilitate host shifts?. PLoS Pathogens, 14, e1006961.

Foerstner, K.U., von Mering, C., Hooper, S.D. \& Bork, P. (2005) Environments shape the nucleotide composition of genomes. EMBO Reports, 6, 1208-1213.

Franzen, J.L. \& Brown, M. (2011) The rise of horses: 55 Million years of evolution. pp. 1-211. The Johns Hopkins University Press.

Geraads, D. (2010) Rhinocerotidae. Cenozoic Mammals of Africa pp. 669-683. University of California Press.

Gowda, A.K.J., Dharanesha, N.K., Giridhar, P. \& Byre Gowda, S.M. (2017) Cobboldia elephantis (Cobbold, 1866) larval infestation in an Indian elephant (Elephas maximus). Journal of Parasitic Diseases, 41, 364366.

Grimaldi, D. \& Engel, M.S. (2005) Evolution of the Insects. pp. 1-732. Cambridge University Press.

Grunin, K. (1973) First discovery of larvae of the mammoth bot-fly Cobboldia (Mamontia, subgen. n.) Russanovi sp. n.(Diptera,-Gasterophilidae). Entomological review, 52, 165-169.

Guimarães, J.H. \& Papavero, N. (1999) Myiasis in man and animals in the Neotropical Region: Bibliographic database. pp. 308. Plêiade.

Holmes, J.C. (1972) Site selection by parasitic helminths: interspecific interactions, site segregation, and their importance to the development of helminth communities. Canadian journal of zoology, 51, 333-347.

Horak, I.G., de Vos, V. \& de Klerk, B.D. (1984a) Parasites of domestic and wild animals in south Africa. XVII. Arthropod parasites of burchell's zebra, Equus burchelli, in the eastern Transvaal Lowveld. Onderstepoort Journal of Veterinary Research, 51, 145-154.

Horak, I.G., Knight, M.M. \& de Vos, V. (1984b) Parasites of domestic and wild animals in South Africa. XX. Arthropod parasites of the Cape Mountain Zebra (Equus zebra zebra). Onderstepoort Journal of Veterinary Research, 53, 127-152.

Horreo, J.L. (2017) Revisiting the mitogenomic phylogeny of Salmoninae: new insights thanks to recent sequencing advances. PeerJ, 5, e3828.

Huizinga, J.D. \& Lammers, W.J.E.P. (2008) Gut peristalsis is governed by a multitude of cooperating mechanisms. AJP: Gastrointestinal and Liver Physiology, 296, G1-G8.

Hurst, L.D. \& Merchant, A.R. (2001) High guanine-cytosine content is not an adaptation to high temperature: A comparative analysis amongst prokaryotes. Proceedings of the Royal Society B: Biological Sciences, 268, $493-497$.

Janis, C.M. (1993) Tertiary Mammal Evolution in the Context of Changing Climates, Vegetation, and Tectonic Events. Annual Review of Ecology and Systematics, 24, 467-500.

Kalb, J.E., Jolly, C.J., Mebrate, A., Tebedge, S., Smart, C., Oswald, E.B., Cramer, D., Whitehead, P., Wood, C.B., Conroy, G.C., Adefris, T., Sperling, L. \& Kana, B. (1982) Fossil mammals and artefacts from the Middle Awash Valley, Ethiopia. Nature, 298, 25-29.

Kalyaanamoorthy, S., Minh, B.Q., Wong, T.K.F., Von Haeseler, A. \& Jermiin, L.S. (2017) ModelFinder: Fast model selection for accurate phylogenetic estimates. Nature Methods, 14, 587-589.

Katoh, K. \& Standley, D.M. (2013) MAFFT multiple sequence alignment software version 7: Improvements in performance and usability. Molecular Biology and Evolution, 30, 772-780.

Kaya, T.T., Mayda, S., Kostopoulos, D.S., Alcicek, M.C., Merceron, G., Tan, A., Karakutuk, S., Giesler, A.K. \& Scott, R.S. (2012)^erefköy-2, a new Late Miocene mammal locality from the Yata an Formation, Mu la, SW Turkey. Comptes Rendus Palevol, 11, 5-12.

Kazanci, N., Sen, S., Seyitoglu, G., De Bonis, L., Bouvrain, G., Araz, H., Varol, B. \& Karadenizli, L. (1999) Geology of a new late Miocene mammal locality in central Anatolia, Turkey. Comptes Rendus de l'Académie des Sciences-Series IIA-Earth and Planetary Science, 329, 503-510.

Kiktev, D.A., Sheng, Z., Lobachev, K.S. \& Petes, T.D. (2018) GC content elevates mutation and recombination rates in the yeast Saccharomyces cerevisiae. Proceedings of the National Academy of Sciences, 115, E7109-E7118.

Kumar, S., Stecher, G. \& Tamura, K. (2016) MEGA7: Molecular Evolutionary Genetics Analysis Version 7.0 for Bigger Datasets. Molecular biology and evolution, 33, 1870-1874.

Lanfear, R., Frandsen, P.B., Wright, A.M., Senfeld, T. \& Calcott, B. (2017) Partitionfinder 2: New methods for selecting partitioned models of evolution for molecular and morphological phylogenetic analyses. Molecular Biology and Evolution, 34, 772-773. 
Lehmann, U. (1984) Notiz über Säugetierreste von der Insel Samos in der Sammlung des GeologischPaläontologischen Instituts und Museums Hamburg. Mitteilungen aus dem GeologischenPaläontologischen Institut der Universität Hamburg, 57, 147-156.

Letunic, I. \& Bork, P. (2016) Interactive tree of life (iTOL) v3: an online tool for the display and annotation of phylogenetic and other trees. Nucleic acids research, 44, W242-W245.

Li, X., Chen, Y., Wang, Q., Li, K., Pape, T. \& Zhang, D. (2018) Molecular and morphological characterization of third instar Palaearctic horse stomach bot fly larvae (Oestridae: Gasterophilinae, Gasterophilus). Veterinary Parasitology, 262, 56-74.

Linn, C., Feder, J.L., Nojima, S., Dambroski, H.R., Berlocher, S.H. \& Roelofs, W. (2003) Fruit odor discrimination and sympatric host race formation in Rhagoletis. Proceedings of the National Academy of Sciences, 100, 11490-11493.

Mayhew, P.J. (2016) Comparing parasitoid life histories. Entomologia Experimentalis et Applicata, 159, 147162.

De Meeûs, T. \& Renaud, F. (2002) Parasites within the new phylogeny of eukaryotes. Trends in Parasitology, 18, 247-250.

Miller, M.A., Pfeiffer, W. \& Schwartz, T. (2010) Creating the CIPRES Science Gateway for inference of large phylogenetic trees. Gateway Computing Environments Workshop, pp. 1-8.

Mooers, A.Ø. \& Holmes, E.C. (2000) The evolution of base composition and phylogenetic inference. Trends in Ecology and Evolution, 15, 365-369.

Nguyen, L.T., Schmidt, H.A., Von Haeseler, A. \& Minh, B.Q. (2015) IQ-TREE: A fast and effective stochastic algorithm for estimating maximum-likelihood phylogenies. Molecular Biology and Evolution, 32, 268274.

Nufio, C.R. \& Papaj, D.R. (2004) Superparasitism of larval hosts by the walnut fly, Rhagoletis juglandis, and its implications for female and offspring performance. Oecologia, 141, 460-467.

Pandolfi, L. \& Tagliacozzo, A. (2015) Stephanorhinus hemitoechus (Mammalia, Rhinocerotidae) from the Late Pleistocene of Valle Radice (Sora, Central Italy) and re-evaluation of the morphometric variability of the species in Europe. Geobios, 48, 169-191.

Pape, T. (2006) Phylogeny and evolution of the bot flies. The Oestrid Flies: Biology, Host-Parasite Relationships, Impact and Management, pp. 20-50. CABI.

Pape, T., Blagoderov, V. \& Mostovski, M.B. (2011) Order Diptera Linnaeus, 1758. Animal Biodiversity: An Outline of Higher-Level Classi cation and Survey of Taxonomic Richness (ed. by Z.-Q. Zhang). Zootaxa, 3148, 222-229.

Pape, T., PiwczyCski, M., Wyborska, D., Akbarzadeh, K. \& Szpila, K. (2017) A new genus and species of hypodermatine bot flies (Diptera: Oestridae). Systematic Entomology, 42, 387-398.

Patton, M.W.S. (1922) Note on the Egg-laying Habits of Cobboldia elephantis, Cobbold. Indian Journal of Medical Research, 10, 63-65.

Petter, A.J. (1962) Redescription et analyse critique de quelques espèces d'Oxyures de la tortue grecque (Testudo graeca L.). Diversité des structures céphaliques (II). Annales de Parasitologie Humaine et Comparée, 37, 140-152.

Principato, M. (1986) A study on the maxillae of third instar larvae of the six Italian Gasterophilus species (Diptera: Gasterophilidae): observations on their taxonomic significance in the identification to the species. Bulletin de la Societe Francaise de Parasitologie, 1, 121-130.

Prothero, D.R. (1993) Fifty million years of rhinoceros evolution. Scientific American Book of Dinosaurs, pp. 82-91.

Prothero, D.R., Guerin, C. \& Manning, E. (1989) The history of the Rhinocerotoidea. The Evolution of Perissodactyls, pp. 321-340. Oxford University Press.

Read, C.P. (1972) Animal parasitism. Prentice Hall.

Rodhain, J. (1915) Note on oviposition by Oestrids of the genera Gyrostigma and Cobboldia.. Bulletin de la Société de Pathologie Exotique, 8, 275-279.

Romiguier, J., Ranwez, V., Douzery, E.J.P. \& Galtier, N. (2010) Contrasting GC-content dynamics across 33 mammalian genomes: Relationship with life-history traits and chromosome sizes. Genome Research, 20, 1001-1009. 
Ronquist, F. (1997) Dispersal-Vicariance Analysis: A New Approach to the Quantification of Historical Biogeography. Systematic Biology, 46, 195-203.

Ronquist, F. \& Huelsenbeck, J.P. (2003) MrBayes 3: Bayesian phylogenetic inference under mixed models. Bioinformatics, 19, 1572-1574.

Salisbury, B. \& Kim, J. (2001) Ancestral state estimation and taxon sampling density. Systematic biology, 50, $557-564$.

Sanders, W.J., Gheerbrant, E., Harris, J.M., Saegusa, H. \& Delmer, C. (2010) Proboscidea. Cenozoic Mammals of Africa, pp. 161-251. University of California Press.

Schad, G.A. (1963) Niche diversification in a parasitic species flock. Nature, 198, 404-406.

Stearns, S.C. (1992) The evolution of life histories, pp. 1-249. Oxford University Press.

Stireman III, J.O., O’Hara, J.E. \& Wood, D.M. (2006) Tachinidae: evolution, behavior, and ecology. Annual Review of Entomolgy, 51, 525-555.

Stireman III, J.O., Cerretti, P., O’Hara, J.E., Blaschke, J.D. \& Moulton, J.K. (2018) Molecular phylogeny and evolution of world tachinidae (DIPTERA). Molecular phylogenetics and evolution.

Timmermans, M.J.T.N., Lees, D.C. \& Simonsen, T.J. (2014) Towards a mitogenomic phylogeny of Lepidoptera. Molecular Phylogenetics and Evolution, 79, 169-178.

Vaidya, G., Lohman, D.J. \& Meier, R. (2011) SequenceMatrix: Concatenation software for the fast assembly of multi-gene datasets with character set and codon information. Cladistics, 27, 171-180.

Van Valen, L. (1973) A new evolutionary theory. Evolutionary Theory, 1, 1-30.

De Vienne, D.M., Refrégier, G., López-Villavicencio, M., Tellier, A., Hood, M.E. \& Giraud, T. (2013) Cospeciation vs host-shift speciation: Methods for testing, evidence from natural associations and relation to coevolution. New Phytologist, 198, 347-385.

Vinogradov, A.E. \& Anatskaya, O. V. (2017) DNA helix: the importance of being AT-rich. Mammalian Genome, 28, 455-464.

Wada, A. \& Suyama, A. (1986) Local stability of DNA and RNA secondary structure and its relation to biological functions. Progress in Biophysics and Molecular Biology, 47, 113-157.

Weigl, S., Testini, G., Parisi, A., Dantas-Torres, F., Traversa, D., Colwell, D.D. \& Otranto, D. (2010) The mitochondrial genome of the common cattle grub, Hypoderma lineatum. Medical and Veterinary Entomology, 24, 329-335.

Weinstein, S.B. \& Kuris, A.M. (2016) Independent origins of parasitism in Animalia. Biology Letters, 12, 20160324.

Van Weyenberg, S., Sales, J. \& Janssens, G.P.J. (2006) Passage rate of digesta through the equine gastrointestinal tract: A review. Livestock Science, 99, 3-12.

Wiegmann, B.M., Trautwein, M.D., Winkler, I.S., Barr, N.B., Kim, J.-W., Lambkin, C., Bertone, M.A., Cassel, B.K., Bayless, K.M., Heimberg, A.M., Wheeler, B.M., Peterson, K.J., Pape, T., Sinclair, B.J., Skevington, J.H., Blagoderov, V., Caravas, J., Kutty, S.N., Schmidt-Ott, U., Kampmeier, G.E., Thompson, F.C., Grimaldi, D.A., Beckenbach, A.T., Courtney, G.W., Friedrich, M., Meier, R. \& Yeates, D.K. (2011) Episodic radiations in the fly tree of life. Proceedings of the National Academy of Sciences, 108, 56905695.

Yan, L., Zhang, M., Gao, Y., Pape, T. \& Zhang, D. (2017) First mitogenome for the subfamily Miltogramminae (Diptera: Sarcophagidae) and its phylogenetic implications. European Journal of Entomology, 114, 422429.

Yu, Y., Harris, A.J. \& He, X. (2010) S-DIVA (Statistical Dispersal-Vicariance Analysis): A tool for inferring biogeographic histories. Molecular Phylogenetics and Evolution, 56, 848-850.

Yu, Y., Harris, A.J., Blair, C. \& He, X. (2015) RASP (Reconstruct Ancestral State in Phylogenies): A tool for historical biogeography. Molecular Phylogenetics and Evolution, 87, 46-49.

Zelmer, D.A. (1998) An evolutionary definition of parasitism. International Journal for Parasitology, 28, 531533.

Zhang, D., Yan, L., Zhang, M., Chu, H., Cao, J., Li, K., Hu, D. \& Pape, T. (2016a) Phylogenetic inference of calyptrates, with the first mitogenomes for Gasterophilinae (Diptera: Oestridae) and Paramacronychiinae (Diptera: Sarcophagidae). International Journal of Biological Sciences, 12, 489-504.

Zhang, D., Li, X., Liu, X., Wang, Q. \& Pape, T. (2016b) The antenna of horse stomach bot flies: Morphology 
and phylogenetic implications (Oestridae, Gasterophilinae: Gasterophilus Leach). Scientific Reports, 6, 34409.

Zietara, M.S. \& Lumme, J. (2002) Speciation by host switch and adaptive radiation in a fish parasite genus Gyrodactylus (Monogenea, Gyrodactylidae). Evolution, 56, 2445-2458.

Zumpt, F. (1965a) Morphology, biology and pathogenesis of myiasis-producing flies. Myiasis in Man and Animals in the Old World: A Textbookfor Physicians, Veterinarians and Zoologists, pp. 108-247. Butterworths.

Zumpt, F. (1965b) Myiasis in Man and Animals in the Old World: A Textbook for Physicians, Veterinarians and Zoologists, Butterworths. 


\section{Tables and Figure legends Tables}

Table 1. Life-history changes with host shifts in stomach bot flies.

\begin{tabular}{|c|c|c|c|c|c|c|}
\hline Species & Host & $\begin{array}{l}\text { Oviposition } \\
\text { site }\end{array}$ & Fecundity & $\begin{array}{l}\text { Attachment } \\
\text { organ (AO) } \\
\text { type }\end{array}$ & $\begin{array}{l}\text { Infecting } \\
\text { strategy of } 1^{\text {st }} \\
\text { instar larvae }\end{array}$ & $\begin{array}{l}3^{\text {rd }} \text {-instar } \\
\text { attachment } \\
\text { location }\end{array}$ \\
\hline $\begin{array}{l}\text { Cobboldia } \\
\text { loxodontis }\end{array}$ & Elephantidae & $\begin{array}{l}\text { Base of the } \\
\text { tusks. }\end{array}$ & Unknown. & Unknown. & Unknown. & Stomach. \\
\hline $\begin{array}{l}\text { Gyrostigma } \\
\text { rhinocerontis }\end{array}$ & Rhinocerotidae & $\begin{array}{l}\text { Mainly on the } \\
\text { head, neck and } \\
\text { shoulders. }\end{array}$ & $\sim 750$ & Type-II AO & Unknown. & Stomach. \\
\hline $\begin{array}{l}\text { Gasterophilus } \\
\text { haemorrhoidalis }\end{array}$ & Equidae & $\begin{array}{l}\text { Lips, mainly } \\
\text { the upper lips. }\end{array}$ & $50-200$ & Type-I AO & $\begin{array}{l}\text { Hatching with } \\
\text { stimulation of } \\
\text { moisture from } \\
\text { host, and } \\
\text { spontaneously } \\
\text { migrating into } \\
\text { the host } \\
\text { mouth. }\end{array}$ & Rectum. \\
\hline Ga. inermis & Equidae & Cheeks. & $320-360$ & Type-I AO & $\begin{array}{l}\text { Spontaneously } \\
\text { hatching and } \\
\text { migrating into } \\
\text { the host } \\
\text { mouth. }\end{array}$ & Rectum. \\
\hline Ga. intestinalis & Equidae & $\begin{array}{l}\text { Mainly lower } \\
\text { forelegs, also } \\
\text { on the back } \\
\text { and flanks. }\end{array}$ & $400-1000$ & Type-I AO & $\begin{array}{l}\text { Hatching and } \\
\text { entering the } \\
\text { host mouth } \\
\text { when licked } \\
\text { by host. }\end{array}$ & Stomach. \\
\hline Ga. nasalis & Equidae & $\begin{array}{l}\text { Under the chin } \\
\text { in the groove } \\
\text { between the } \\
\text { halves of the } \\
\text { lower jaw. }\end{array}$ & $300-500$ & Type-I AO & $\begin{array}{l}\text { Spontaneously } \\
\text { hatching and } \\
\text { migrating into } \\
\text { the host } \\
\text { mouth. }\end{array}$ & $\begin{array}{l}\text { Near the } \\
\text { pylorus. }\end{array}$ \\
\hline Ga. nigricornis & Equidae & $\begin{array}{l}\text { On the cheeks, } \\
\text { rarely on the } \\
\text { nasal region. }\end{array}$ & $330-350$ & Type-I AO & $\begin{array}{l}\text { Spontaneously } \\
\text { hatching and } \\
\text { migrating into } \\
\text { the host } \\
\text { mouth. }\end{array}$ & Duodenum. \\
\hline $\begin{array}{l}\text { Ga. } \\
\text { meridionalis }\end{array}$ & Equidae & Unknown. & Unknown. & Type-I AO & Unknown. & $\begin{array}{l}\text { Pylorus and } \\
\text { duodenum. }\end{array}$ \\
\hline Ga. pecorum & Equidae & $\begin{array}{l}\text { Leaves and } \\
\text { stems of } \\
\text { plants, mainly } \\
\text { grasses. }\end{array}$ & $\begin{array}{l}1300- \\
2500\end{array}$ & Type-II AO & $\begin{array}{l}\text { Hatching and } \\
\text { entering the } \\
\text { host mouth } \\
\text { when eaten by } \\
\text { host. }\end{array}$ & $\begin{array}{l}\text { Pharynx and } \\
\text { stomach. }\end{array}$ \\
\hline
\end{tabular}


Table 2. Taxon sampling in the present study.

\begin{tabular}{lll}
\hline Species & $\begin{array}{l}\text { GenBank accession } \\
\text { number }\end{array}$ & Reference \\
\hline Dermatobia hominis & NC_006378 & (Azeredo-Espin et al., 2004) \\
Hypoderma lineatum & NC_013932 & (Weigl et al., 2010) \\
Gasterophilus pecorum & NC_029812 & (Zhang et al., 2016a) \\
Gasterophilus haemorrhoidalis & MG920502 & Present study \\
Gasterophilus inermis & MG920503 & Present study \\
Gasterophilus intestinalis & MG920504 & Present study \\
Gasterophilus nasalis & MG920505 & Present study \\
Gasterophilus nigricornis & MG920506 & Present study \\
Gyrostigma rhinocerontis & MK045312 & Present study \\
Cobboldia loxodontis & MK045310-MK045311 & Present study \\
\hline
\end{tabular}

This article is protected by copyright. All rights reserved. 
Table 3. Characters used for ancestral state estimation in the present study.

\begin{tabular}{|c|c|c|c|}
\hline Species & Geographic distribution & Oviposition site & $\begin{array}{l}3^{\text {rd }} \text { instar larvae } \\
\text { attaching location }\end{array}$ \\
\hline Dermatobia hominis & Neotropic & Environment & Subdermal tissue \\
\hline Hypoderma lineatum & Palearctic & $\begin{array}{l}\text { Non-head area } \\
\text { of host body }\end{array}$ & Subdermal tissue \\
\hline Cobboldia loxodontis & $\begin{array}{l}\text { Afrotropic }{ }^{\mathrm{a}} / \text { Afrotropic }+ \\
\text { Palearctic }+ \text { Oriental }^{\mathrm{b}}\end{array}$ & $\begin{array}{l}\text { Head area of } \\
\text { host body }\end{array}$ & Stomach \\
\hline Gyrostigma rhinocerontis & Afrotropic & $\begin{array}{l}\text { Non-head and } \\
\text { head area of } \\
\text { host body }\end{array}$ & Stomach \\
\hline Gasterophilus pecorum & Afrotropic + Palearctic & Environment & Pharynx + Stomach \\
\hline Ga. haemorrhoidalis & Afrotropic + Palearctic & $\begin{array}{l}\text { Head area of } \\
\text { host body }\end{array}$ & Large intestine \\
\hline Ga. inermis & Afrotropic + Palearctic & $\begin{array}{l}\text { Head area of } \\
\text { host body }\end{array}$ & Large intestine \\
\hline Ga. ternicinctus & Afrotropic & Unknown & Stomach \\
\hline Ga. intestinalis & Palearctic & $\begin{array}{l}\text { Non-head area } \\
\text { of host body }\end{array}$ & Stomach \\
\hline Ga. nasalis & Afrotropic + Palearctic & $\begin{array}{l}\text { Head area of } \\
\text { host body }\end{array}$ & $\begin{array}{l}\text { Pylorus and } \\
\text { duodenum }\end{array}$ \\
\hline Ga. meridionalis & Afrotropic & Unknown & $\begin{array}{l}\text { Pylorus and } \\
\text { duodenum }\end{array}$ \\
\hline Ga. nigricornis & Palearctic & $\begin{array}{l}\text { Head area of } \\
\text { host body }\end{array}$ & $\begin{array}{l}\text { Pylorus and } \\
\text { duodenum }\end{array}$ \\
\hline
\end{tabular}

\footnotetext{
${ }^{\mathrm{a}}$ Distribution of Cobboldia loxodontis coded as Afrotropical.

${ }^{\mathrm{b}}$ Distribution of Cobboldia loxodontis coded as Afrotropic + Palearctic + Oriental.
} 


\section{Figure legends}

Fig. 1 Base composition and family-specific substitution rate of 13 mitochondrial proteincoding genes in calyptrates.

A - Guanine and Cytosine (GC) content of calyptrate mitogenomes; B1 - Mean evolutionary rates of each family estimated by dividing total amount of the Tamura-Nei substitution by divergence times; B2 - Mean evolutionary rates of each family estimated by dividing total amount of substitution at fourfold degenerate sites by divergence times; B3 - Mean evolutionary rates of each family estimated by dividing total amount of synonymous substitution by divergence times; B4 - Mean evolutionary rates of each family estimated by dividing total amount of non-synonymous substitution rates into divergence times. Error bars represent standard deviation from data of multiple species pairs.

Fig. 2 Phylogeny of stomach bot flies inferred from mitogenomic data.

Dashed branches indicate taxa placement based on morphological characters only. Numbers at the nodes are posterior probabilities (Bayesian trees) / Bootstrap values (ML trees) for molecular phylogeny construction.

Fig. 3 Estimation of geographical origin of stomach bot flies.

Left - DIVA estimation based on proposed Gasterophilus species tree. Right - Migrating routes of Proboscidea, Rhinocerotidae and Equidae since 20 million years ago, as indicated by the literature (Bernor et al., 2010; Geraads, 2010; Sanders et al., 2010; Franzen \& Brown, 2011).

Fig. 4 Reconstructions of ancestral oviposition sites of stomach bot flies.

Cladograms from top to bottom are reconstruction using MP, BBM and S-DIVA respectively. Possibility (MP) or probability of each possibility (BBM and S-DIVA) for each node is shown as color proportion on the node. Eggs above cladograms are Cobboldia elephantis ${ }^{*}$, Gyrostigma rhinocerontis, Gasterophilus pecorum, Ga. ternicinctus, Ga. intestinalis, Ga. haemorrhoidalis, Ga. inermis, Ga. nasalis, Ga. meridionalis and Ga. nigricornis respectively from left to right, with structure of Type-II attachment organ (AO) highlighted in arctic blue, and Type-I AO pink. Known oviposition sites of each species are illustrated on the top scenario distinguished with different colors.

${ }^{*}$ This is the only egg of Cobboldia recorded by literature (Patton, 1922).

Fig. 5 Reconstructions of ancestral $3^{\text {rd }}$ instar larvae attaching locations of stomach bot flies. Cladograms from top to bottom are reconstructed using MP, BBM and S-DIVA respectively. Possibility (MP) or probability of each possibility (BBM and S-DIVA) for each node are shown as a color proportion on the node. 
A

GC content of calyptrate mitochondrial genome

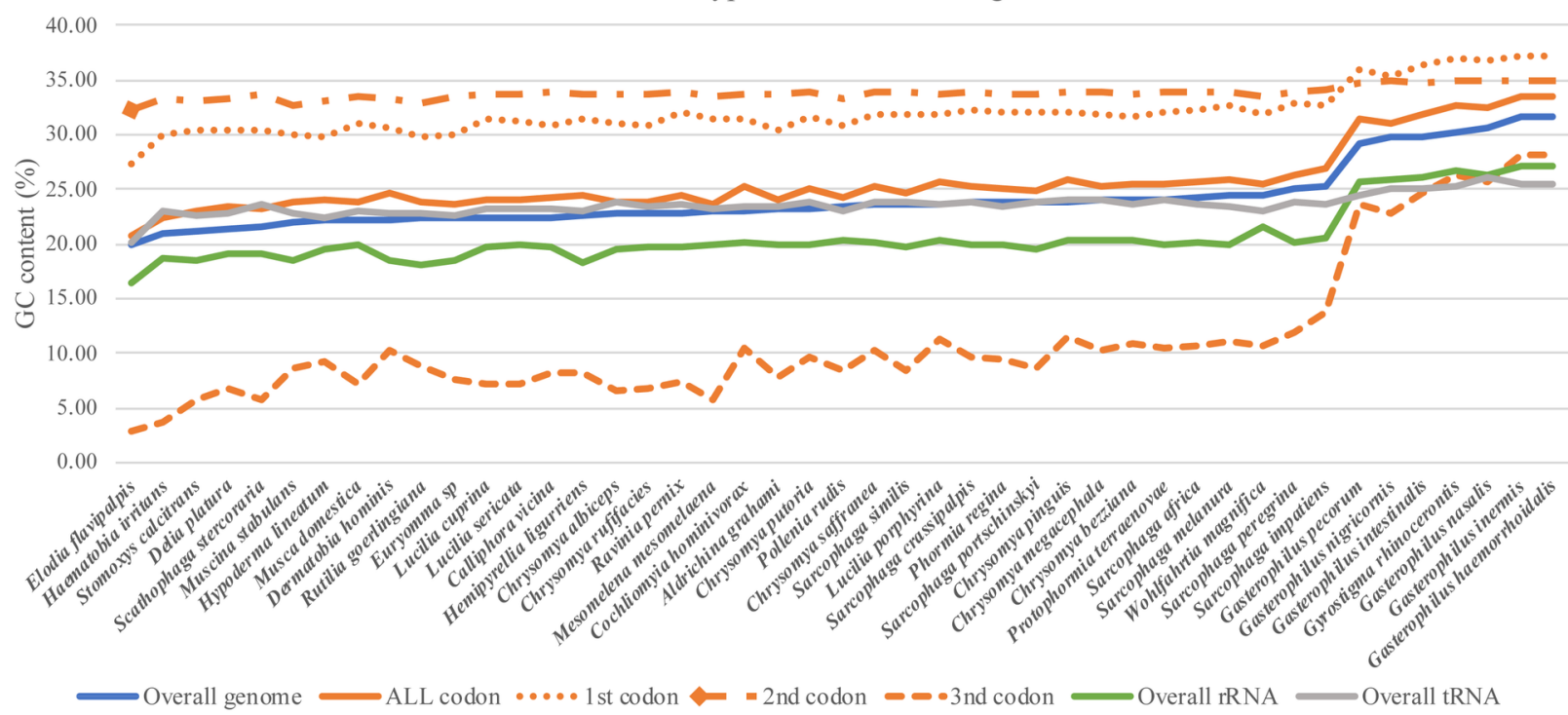

B1

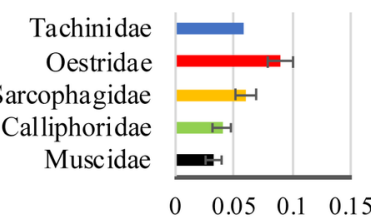

B2

Tachinidae Oestridae Sarcophagidae Calliphoridae Muscidae

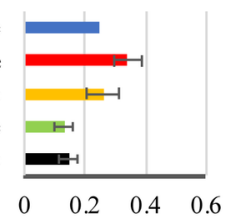

B3

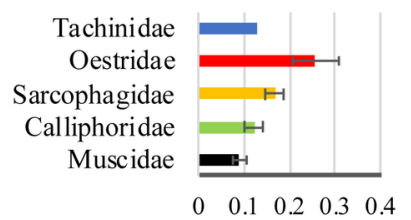

B4

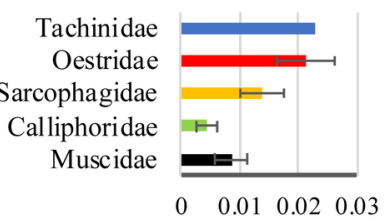

SYEN_12356_Fig_1.tif 


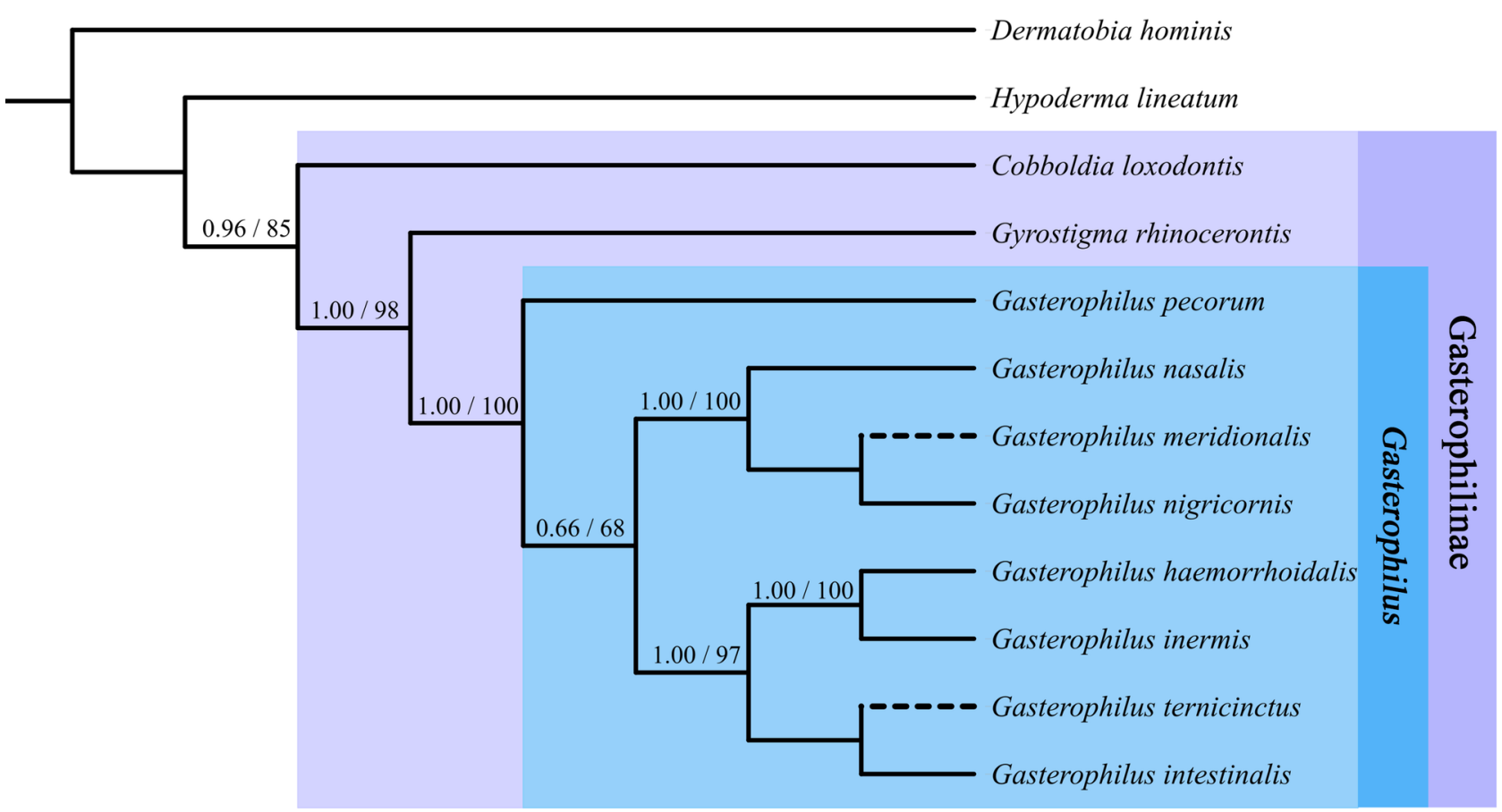

SYEN_12356_Fig_2.tif

This article is protected by copyright. All rights reserved. 


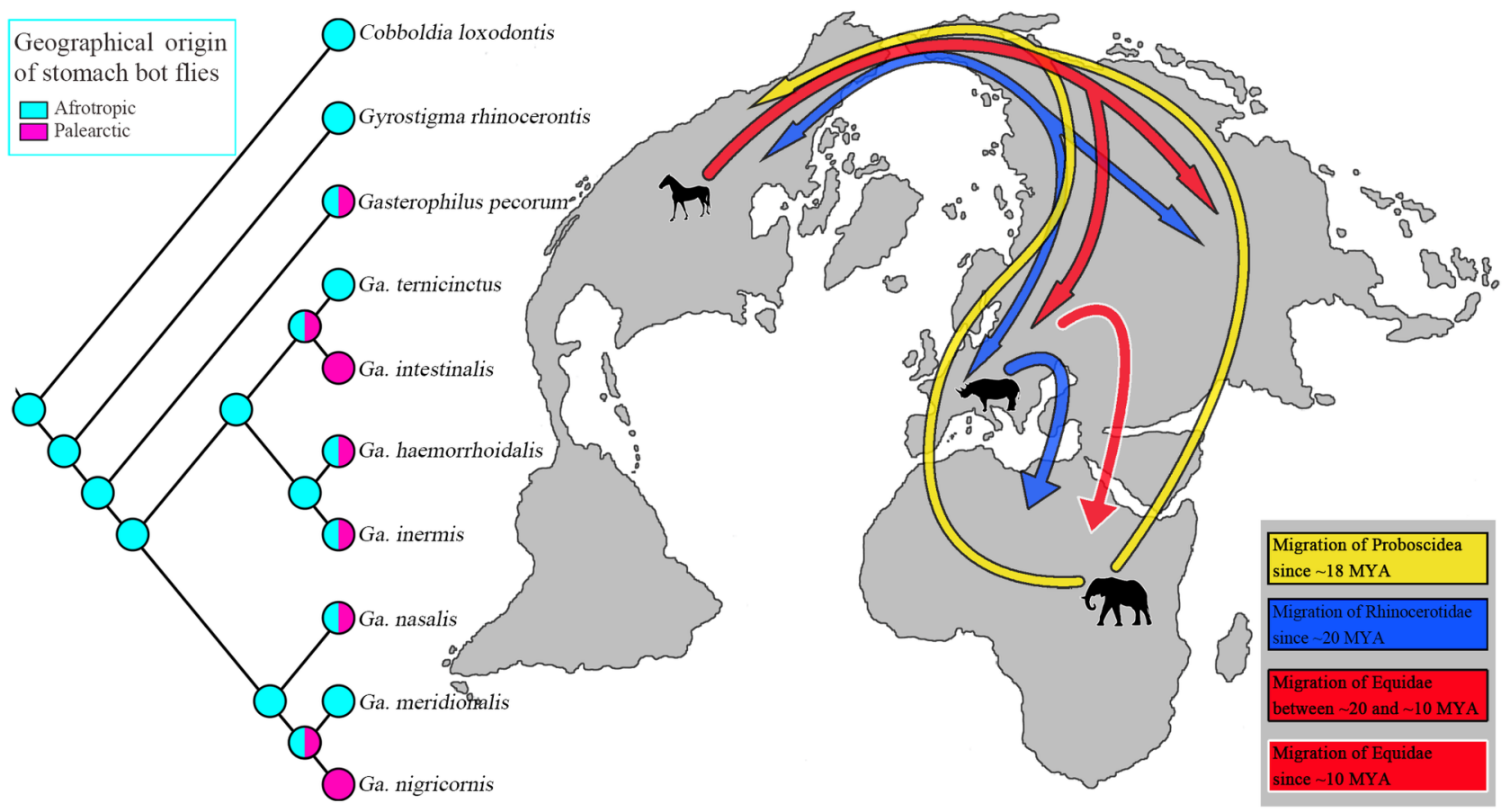

SYEN_12356_Fig_3_Gasterophilus_origin.tif 

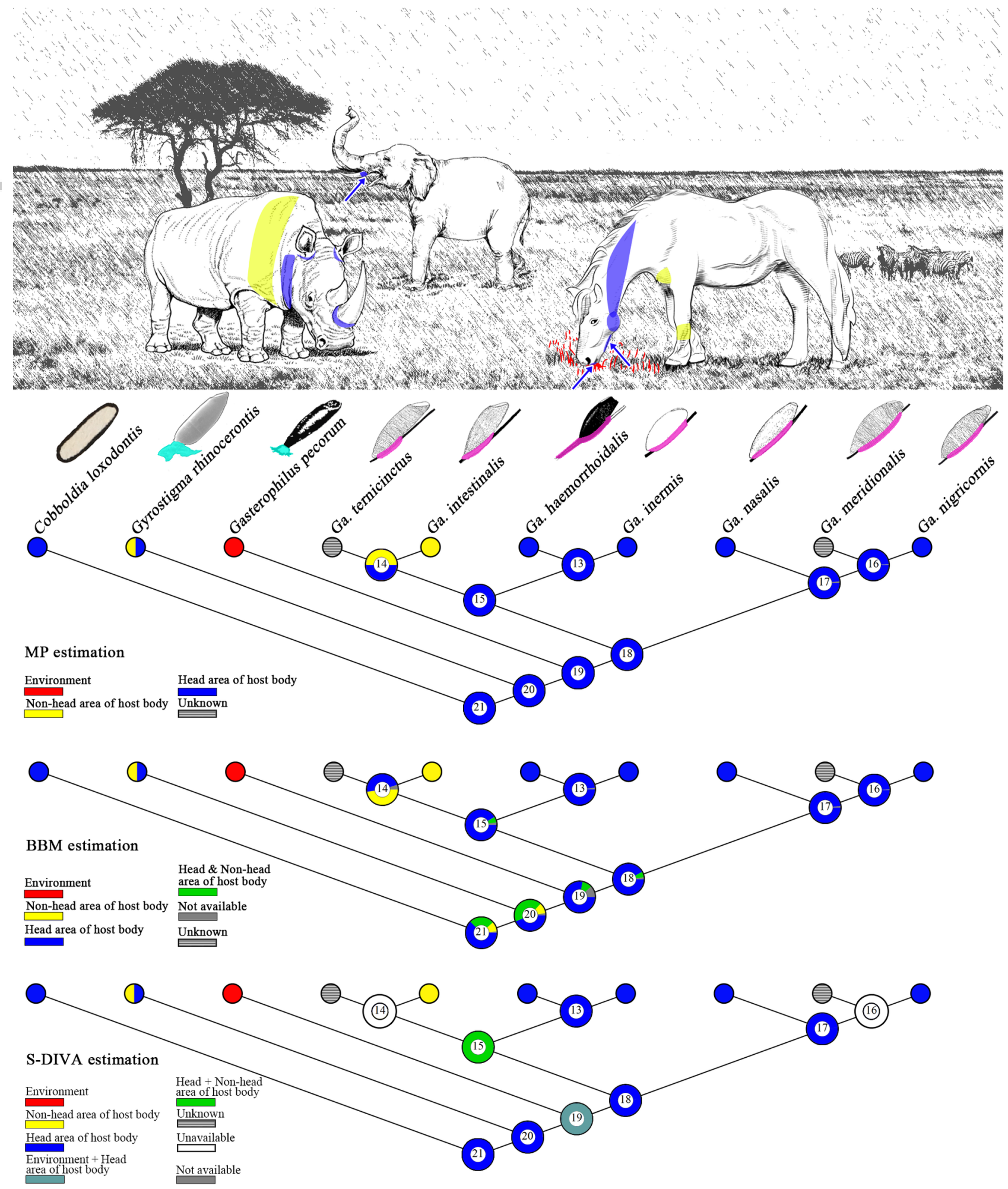

SYEN_12356_Fig_4_oviposition_site.tif 

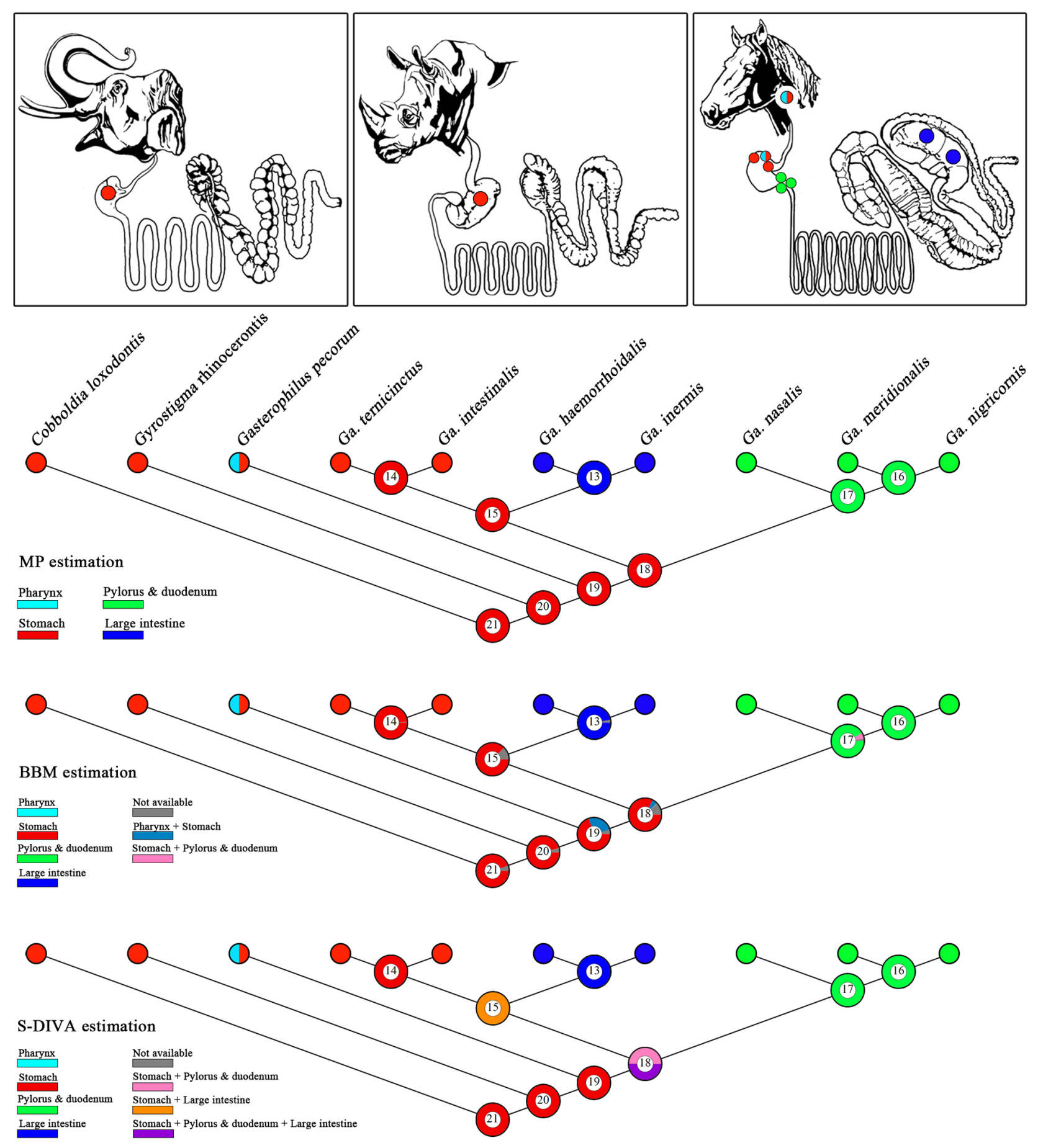

SYEN_12356_Fig_5_3rd_instar_attaching_site.tif 


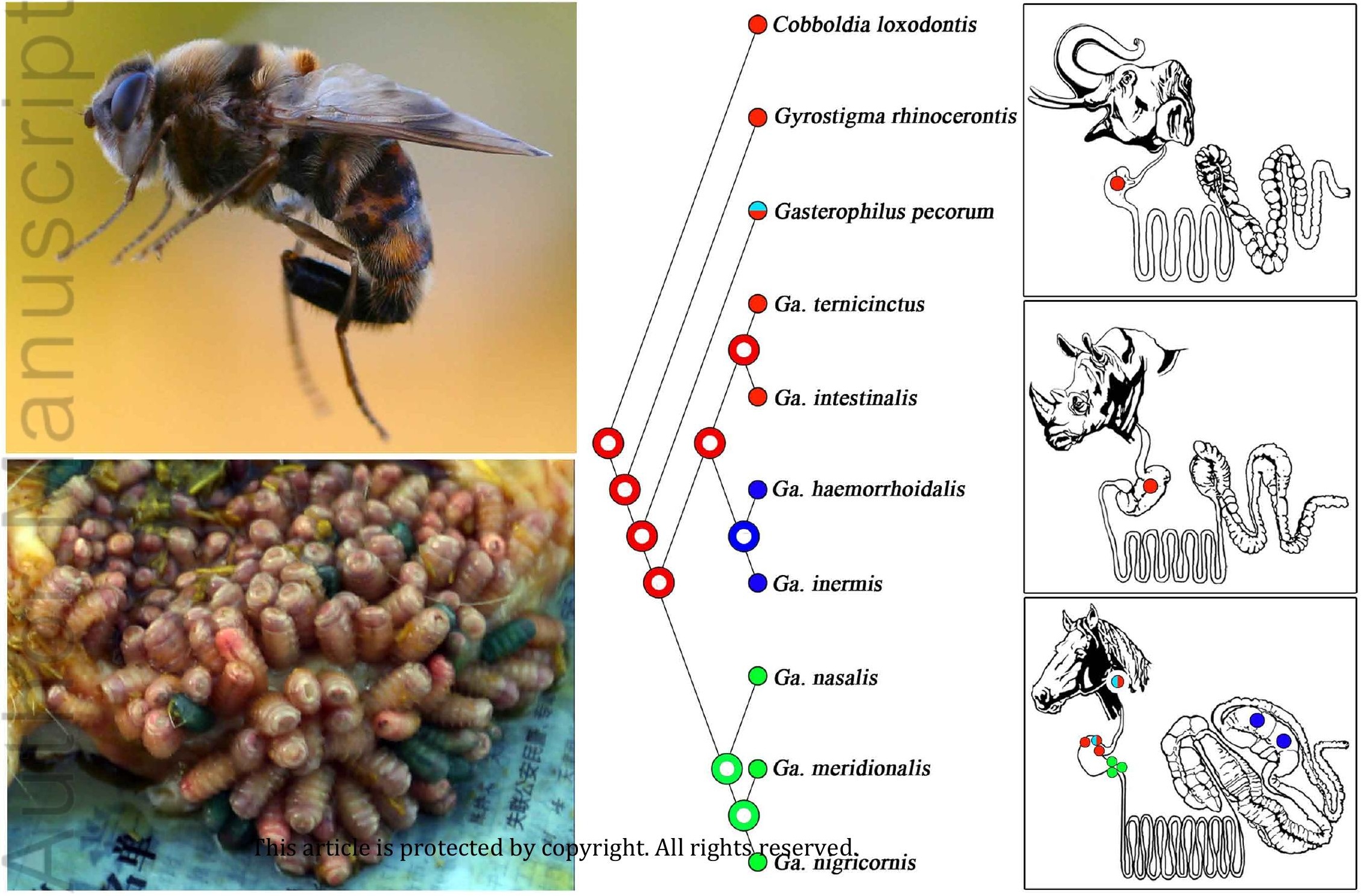


Evolutionary history of stomach bot flies in the light of mitogenomics

Liping Yan ${ }^{1}$, Thomas Pape ${ }^{2}$, Mark A. Elgar ${ }^{3}$, Yunyun Gao ${ }^{1}$, Dong Zhang ${ }^{1, *}$

${ }^{1}$ School of Nature Conservation, Beijing Forestry University, Beijing 100083, China

${ }^{2}$ Natural History Museum of Denmark, University of Copenhagen, Copenhagen 2100, Denmark

${ }^{3}$ School of BioSciences, University of Melbourne, Melbourne, Victoria 3010, Australia

${ }^{*}$ Correspondence: ernest8445@163.com, zhangdong_bjfu@bjfu.edu.cn

\section{Highlights}

The phylogeny of stomach bot flies (Oestridae: Gasterophilinae) is reconstructed based on mitogenomic data.

Host shifts and evolution of oviposition site and location of $3^{\text {rd }}$ instar larva are reconstructed.

Mitogenomes of stomach bot flies have the highest GC-ratio of all calyptrate flies, which may be an adaptation to larval life in the mammalian body. 


\section{University Library}

\section{- M M I N E R VA A gateway to Melbourne's research publications}

Minerva Access is the Institutional Repository of The University of Melbourne

Author/s:

Yan, L;Pape, T;Elgar, MA;Gao, Y;Zhang, D

Title:

Evolutionary history of stomach bot flies in the light of mitogenomics

Date:

2019-10-01

Citation:

Yan, L., Pape, T., Elgar, M. A., Gao, Y. \& Zhang, D. (2019). Evolutionary history of stomach bot flies in the light of mitogenomics. SYSTEMATIC ENTOMOLOGY, 44 (4), pp.797-809. https://doi.org/10.1111/syen.12356.

Persistent Link:

http://hdl.handle.net/11343/285635 